\section{Grape Tomato Breeding Lines: NC 1 Grape, NC 2 Grape, and NC 3 Grape}

Randy G. Gardner and Dilip R. Panthee ${ }^{1}$

Department of Horticultural Science, North Carolina State University, Mountain Horticultural Crops Research and Extension Center (MHCREC), 455 Research Drive, Mills River, NC 28759-3423

Additional index words. Brachytic ( $b r$ ) gene, compact growth, early blight resistance, flavor, rin gene, shelf life, sugar content

Over the last several years, grape tomato production has grown to become an important segment of fresh-market tomatoes and strongly competes for market share with cherry tomatoes. Demand for grape tomatoes has increased as a result of consumer satisfaction with their vine-ripened flavor, especially their high sugar content, and desirable fruit size and crisp texture. Breeding of improved grape tomato types in the North Carolina fresh-market tomato breeding program has resulted in the release of three breeding lines, NC 1 Grape, NC 2 Grape, and NC 3 Grape, that are useful in producing improved cultivars of grape tomatoes. NC 1 Grape and NC 2 Grape have indeterminate growth habit, whereas NC 3 Grape has determinate growth habit. NC 1 Grape and NC 3 Grape have jointless fruit pedicels, whereas NC 2 Grape has jointed pedicels. NC 1 Grape and NC 3 Grape develop a uniform bright red exterior and interior color in ripe fruits, whereas NC 2 Grape develops a deep yellowish orange color on mature fruit.

\section{Origin}

NC 1 Grape, NC 2 Grape, and NC 3 Grape tomato lines were developed from a breeding effort initiated in 1999 with the grape tomato hybrid 'Santa' crossed with small-fruited, determinate tomato lines with ovate fruit shape developed from earlier breeding in the program (Figs. 1 and 2). 'Santa' contributed indeterminate growth habit for NC 1 Grape and NC 2 Grape and desirable fruit size, shape, texture, and high sugar content. NC 1 Grape and NC 3 Grape share the same pedigree up to the $\mathrm{F}_{3}$ generation from the final cross (99451) leading to their development (Fig. 1). Selection in the $F_{3}$ generation produced indeterminate and determinate growth habits for NC 1 Grape and NC 3 Grape, respectively. NC EBR-6 plum tomato, a parent of the $\mathrm{F}_{1}$

Received for publication 25 Aug. 2010. Accepted for publication 21 Sept. 2010.

The tomato breeding program of NC State University was supported by the North Carolina Tomato Growers Association and the Hatch project of USDA.

${ }^{1}$ To whom reprint requests should be addressed; e-mail Dilip_panthee@ncsu.edu. hybrid 'Plum Dandy' (Gardner, 2000a), provided the brachytic gene (br) for short internodes and resultant compact growth habit in all three grape tomato lines. NC EBR-6 also served as a source of moderate early blight resistance in the three lines. NC $2 \mathrm{C} m s-10$, $a a$ (Gardner, 2000b) was a source of the $m s-10$ gene for male sterility linked to the green stem seedling marker gene, $a a$, which is segregating in NC 3 Grape.

The pedigree of NC 2 Grape involves an $F_{2}$ generation selection from the same $F_{1}$ plant selection (99451-2) that led to the de- velopment of the other two grape lines $\times$ an $\mathrm{F}_{2}$ generation selection from 99456-6 (Fig. 2). NC 2 Grape has the ripening inhibitor gene (rin) derived from the large fruited rin line 9565(x)-3.

\section{Description}

'Santa' is a popular grape hybrid tomato and is used as a standard control in variety trials. All three grape tomato lines have uniform light green shoulder color ( $u$ gene) of unripe fruit in contrast to the dark green shoulder color of unripe fruit of 'Santa'. NC 1 Grape and NC 3 Grape have the $j-2$ gene for jointless fruit pedicels, whereas NC 2 Grape has jointed pedicels. Ripe fruit of all three lines separate easily from pedicels during harvest. NC 1 Grape and NC 3 Grape develop a uniform bright red exterior and interior color when ripe and have been free of the yellow shoulder and yellow eye disorders of fruit coloring that sometimes occur with fruit of 'Santa'. NC 2 Grape develops a deep yellowish orange color on mature fruit. Ripe fruit of all three lines are firm and resistant to fruit bursting. Foliage of all three lines is dark green with smaller, narrower leaflets than the foliage of 'Santa'.

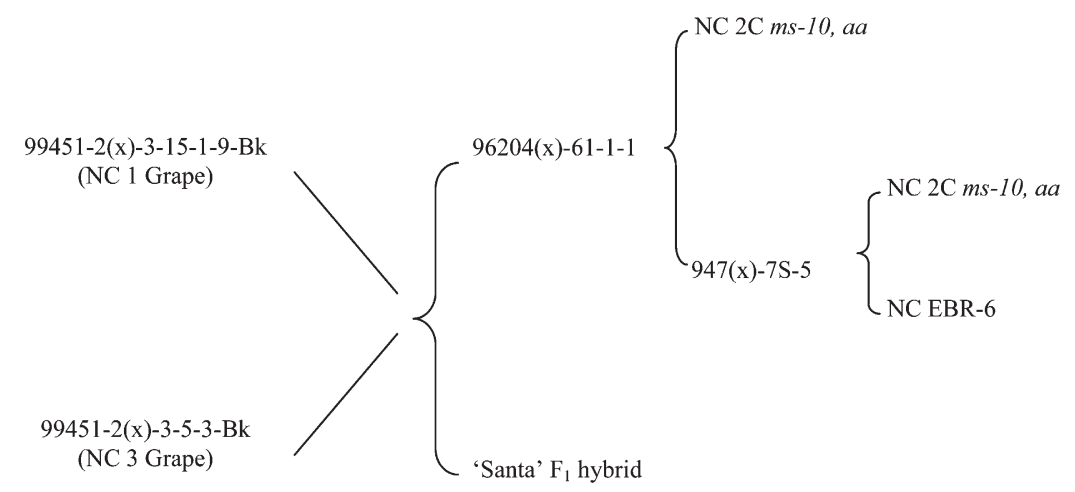

Fig. 1. Pedigree of NC 1 Grape and NC 3 Grape tomato breeding lines.

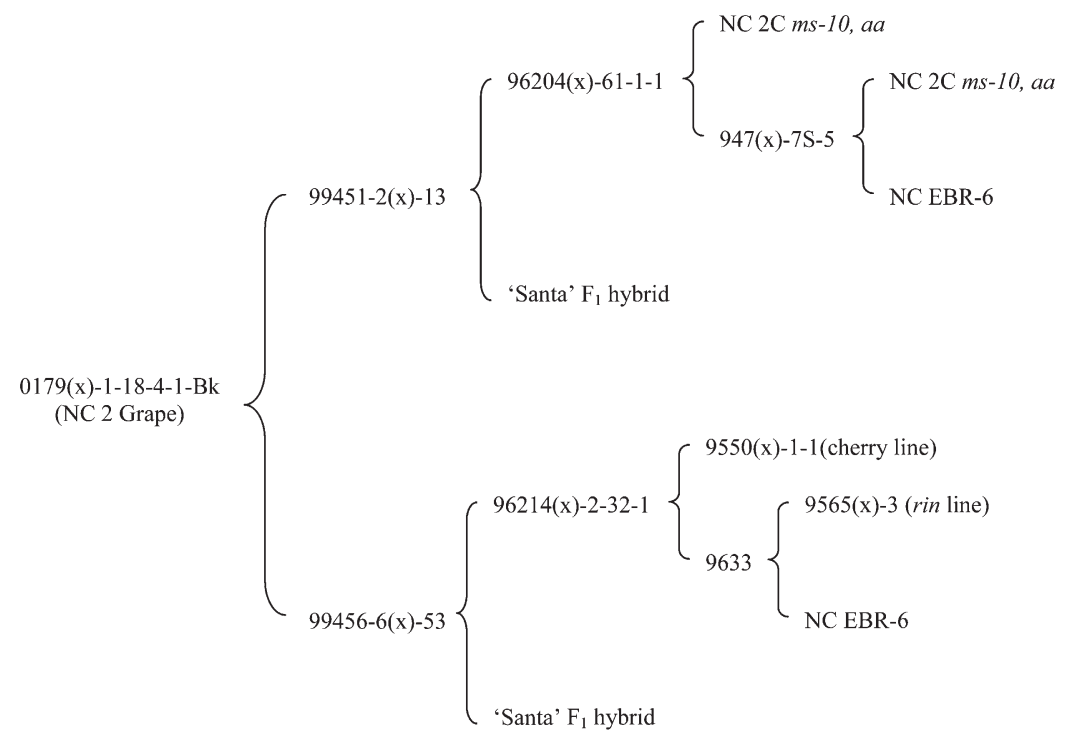

Fig. 2. Pedigree of NC 2 Grape tomato breeding line. 
Table 1. Total soluble solid (TSS) content, average fruit weight, length, and diameter of grape tomato breeding lines grown in the greenhouse, Spring 2010.

\begin{tabular}{lccccc}
\hline Genotype & TSS $(\%)^{\mathrm{z}}$ & Avg fruit wt $(\mathrm{g})^{\mathrm{y}}$ & ${\text { Length }(\mathrm{mm})^{\mathrm{y}}}$ & Diam $(\mathrm{mm})^{\mathrm{y}}$ & Length/diam ratio \\
\hline NC1 Grape & 8.6 & 13 & 34.5 & 25.5 & $1.4 / 1$ \\
NC2 Grape & 8.4 & 14 & 38.5 & 25 & $1.5 / 1$ \\
NC3 Grape & 7.2 & 11 & 30.5 & 26.3 & $1.2 / 1$ \\
Santa & 8.5 & 14.5 & 33.3 & 29 & $1.1 / 1$ \\
Smarty & 8.6 & 13.5 & 36.3 & 26.8 & $1.4 / 1$ \\
LSD $_{(0.05)}$ & 0.7 & 1.6 & 2.2 & 1.4 & 0.1 \\
\hline
\end{tabular}

${ }^{\mathrm{z}}$ Mean of six fruits per replicate at three different dates for four replicates.

${ }^{\mathrm{y}}$ Mean of 20 fruits per replicate in four replications.

LSD $=$ least significant difference.

NC 1 Grape and NC 2 Grape produce high levels of total soluble solids (TSS) and did not differ from 'Santa' in a replicated trial grown in the greenhouse (Table 1). NC 3 Grape was lower than other entries in trial, presumably because of its determinate growth habit resulting in a higher fruit/foliage ratio than the indeterminate entries. This finding is in agreement with previous research showing lower TSS in determinate compared with indeterminate tomato lines (Emery and Munger, 1970). Average fruit weight of NC 1 Grape and NC 2 Grape did not differ from that of 'Santa' and 'Smarty' (NC 3 Grape $\times$ NC 2 Grape $F_{1}$ hybrid). Average fruit weight of $\mathrm{NC} 3$ Grape was lower than other entries in trial (Table 1). Mean fruit length of NC 1 Grape did not differ from that of 'Santa', whereas fruit length of NC 2 Grape was longer than that for 'Santa', and fruit length of NC 3 Grape was shorter than that of 'Santa'. Fruit diameter did not differ among the three grape lines and was less than that for 'Santa'. Length/diameter ratio of NC 1 Grape, NC 2 Grape, and 'Smarty' was greater than that of NC 3 Grape and 'Santa'. Fruit of NC 1 Grape and NC 3 Grape are fairly elliptical in shape, whereas fruit of NC 2 Grape sometimes have a slight pear shape and exhibit slight nippling of blossom ends. Pictures of the three grape tomato lines are available at the following web site: http://www.ces.ncsu.edu/ fletcher/programs/tomato/releases/seedlines. html.

\section{Use}

NC 1 Grape, NC 2 Grape, and NC 3 Grape have desirable combinations of plant and fruit traits that widen the germplasm available for improving new grape tomato cultivars. Their short internode length resulting from the brachytic gene allows for the development of compact indeterminate cultivars that can be produced on shorter trellises than tallgrowing cultivars such as 'Santa'. The $u$ gene for uniform light green color of unripe fruit results in uniform ripening without the occurrence of yellow shoulder and yellow eye that sometimes occurs with dark green shoulder color of unripe fruit of 'Santa' and some other grape tomato cultivars. The rin gene of NC 2 Grape is useful in developing tomato hybrids with extended shelf life. Although rin is classified as recessive in action, it is not completely recessive and exerts influence in the heterozygous condition in delaying fruit ripening and softening when used in hybrids. 'Smarty', the hybrid of NC 3 Grape $\times$ NC 2 Grape, is licensed by Harris Moran Seed Co. for seed production and sales. It has gained significant market share for grape tomato production because of its desirable combina- tion of compact growth habit, its extended shelf life resulting from the rin gene, and its high yields of high-quality fruit. NC 3 Grape has potential for use as a parent in other grape tomato hybrids, especially when crossed with indeterminate lines because of its segregation for the $m s-10$, a a gene combination for male sterility linked to the green stem seedling marker, which comes from NC 2C (Gardner, 1993). Male sterility greatly facilitates hybrid seed production by eliminating the need for emasculation of the female parent in producing $F_{1}$ seed. It also eliminates the problem of self-pollinated plants of the female parent showing up in the $\mathrm{F}_{1}$ hybrid.

\section{Availability}

Small trial samples of the three grape tomato breeding lines are available from D.R. Panthee (dilip_panthee@ncsu.edu) or R.G. Gardner (randy_gardner@ncsu.edu),MHCREC, 455 Research Drive, Mills River, NC 28759. Recipients of the breeding lines are required to sign a seed transfer agreement, which can be downloaded from the following web site: http://www.mountainhort.ncsu.edu/programs/ tomato/releases/tomato-seed-transfer-agreement. pdf.

\section{Literature Cited}

Emery, G.C. and H.M. Munger. 1970. Effects of inherited differences in growth habit on fruit size and soluble solids in tomato. J. Amer. Soc. Hort. Sci. 95:410-412.

Gardner, R.G. 1993. Mountain Belle Cherry Tomato- $\mathrm{NC}-1 \mathrm{C}$ and NC-2C Cherry Tomato breeding lines. HortScience 28:349-350.

Gardner, R.G. 2000a. 'Plum Dandy', A hybrid tomato, and its parents, NC EBR-5 and NC EBR-6. HortScience 35:962-963.

Gardner, R.G. 2000b. A male-sterile cherry tomato breeding line, $\mathrm{NC} 2 \mathrm{C}$ ms-10,aa. HortScience 35:964-965. 